\title{
De oorsprong van de moderne duivensport
}

Thomas Verbeke

\section{Inleiding}

Dit artikel wil een bescheiden bijdrage zijn in de geschiedschrijving van een vorm van volksvermaak: de duivensport. Wegens het volkse karakter nooit echt naar waarde geschat in de moderne vaderlandse geschiedschrijving, maar wel volksvermaak nummer één tijdens het interbellum. In een slotbeschouwing wordt eveneens in het kort gesuggereerd hoe het spel met de duiven een parameter zou kunnen zijn in een quantitatieve benadering van welvaart of welzijn van de spelers.

De band tussen mens en duif reikt evenwel verder dan de thans beoefende spelvorm. Zonder in oppervlakkige anekdotiek te willen vervallen lijkt het interessant om eerst even dieper in te gaan op de voorgeschiedenis van de hedendaagse liefhebberij.

\section{Chronologie}

Een geschiedenis van de duivensport opstellen is minder eenvoudig dan het lijkt. Een eerste vraag die men zich daarbij moet stellen betreft het aanvangspunt: indien men zich rigoureus aan de definitie van "de duivensport" houdt dan zou de chronologie ergens in het begin van de vorige eeuw moeten beginnen. Op zich is daar niets verkeerd mee, maar dan gaat men wel voorbij aan het onderliggende domesticatieproces dat de (moderne) duivenmelker de mogelijkheid gaf om met zijn dieren te spelen.

Gaat men evenwel even dieper in op dat domesticatieproces, dan moet men - wil men volledig zijn - onvermijdelijk aspecten belichten die verder af staan van het (huidige) spel, maar die toch van belang zijn omdat ze bepalend geweest zijn voor de relatie mens duif.

Om het overzicht te bewaren leek het mij dan ook aangewezen om deze paragraaf op te delen in een aantal items. Deze zijn: "de eigenlijke domesticatie en de domesticatieregio's", "de duif als communicatiemiddel”, “de duif als symbolisch/allegorisch en sacraal gegeven" en het "ontstaan van het hedendaagse duivenspel". 


\section{De eigenlijke domesticatie en de domesticatieregio's}

De domesticatie van duiven geschiedde min of meer onafhankelijk van elkaar in een aantal verschillende regio's in Azië en NoordAfrika.

De oudste verwijzing gaat terug tot het Egypte van de vijfde dynastie ca. 3000 voor onze jaartelling. (') Hier dient wel opgemerkt te worden dat de duif in Egypte vooral met het oog op consumptie werd gekweekt. Niettemin ontwikkelde er zich een traditie van duivenmelken die voortleeft tot op heden. Daarvan getuigen de talrijke duiventillen die nu nog in Egypte te vinden zijn.

Als tweede entiteit onderscheiden we China. Voor deze regio ontbreekt het aan exacte data, maar de traditionele Chinese overlevering leert ons dat ca. 700 voor onze jaartelling de duif gedomesticeerd was. $\left({ }^{2}\right)$ Er ontwikkelde zich dan ook een bloeiende duivenliefhebberij, al was deze vooral gericht op het kweken van sier- en volièreduiven met als gevolg dat er in China talrijke sierduivenpopulaties ontstonden.

Een derde domesticatieregio is het gebied tussen Tigris en Eufraat. Verschillende bronnen wijzen in de richting van de Assyriërs die de duif als militaire boodschapper inzetten (zie verder). ( ${ }^{3}$ )

Tot slot schuiven sommigen de Hebreeuwen naar voren als de onderwerpers van de duif aan de mens $\left({ }^{4}\right)$ waarbij steevast verwezen wordt naar het bijbelboek Genesis - en meer bepaald naar de zondvloedpassage, $\left({ }^{5}\right)$ waarin een duif met een twijg tussen de bek komt aangevlogen en aldus aangeeft dat er nog land bestond (zie verder). Los van de inhoud van het verhaal is het natuurlijk wel een feit dat er hier naar een relatie mens - dier wordt verwezen die wijst op domesticatie.

\section{De duif als communicatiemiddel}

In een tijd waarin de boodschapper te paard zowat het snelste communicatiemiddel over land was, was het vermogen om duiven af te richten vanuit strategisch oogpunt een fenomenale troef. Doorheen de eeuwen zijn er dan ook tal van voorbeelden op te sommen van veldslagen die (mede)beslist werden door het inzetten van duiven.

De eersten die zich bekwaamden in het africhten van duiven met communicatieve bedoelingen waren de Assyriërs en de Feniciërs,
(1) Encyclopedia Britannica, p. 437.

(2) BOUQUET Y.H., syllabus etmognạfie. Hoofdstuk duiven. s.l., s.d., p. 2

(3) WITTOUCK S., De Duivenliefuedberij. Wetenschappelijk handboek. Gent, Stepman, 1891, p. 2.

(4) BOGAERTS F., Histoire civile et religieuse de la colombe. Anvers, Buchman, 18.47. $1 \mathrm{p} .69-71$.

(5) Cinesis 8,12 
die op deze manier vooral militaire informatie uitwisselden $\left({ }^{6}\right)$ : een duif kon berichten over een afstand van ongeveer honderd kilometer over vliegen zonder dat ze in handen van de vijand konden vallen. De boodschap werd in een kokertje aan de duif bevestigd.

Ca. 500 voor onze jaartelling werd deze techniek eerst door de Grieken $\left({ }^{7}\right)$ en later door de Romeinen overgenomen. Het waren deze laatsten die de duif introduceerden in Europa. Zo zou Brutus - volgens Plinius - zich in het jaar 43 voor Christus bij de belegering van Modena bediend hebben van postduiven om hulp te vragen aan zijn vrienden buiten de belegerde plaats. ${ }^{8}$ )

$\mathrm{Nu}$ is het wel zo dat het aantal verwijzingen naar het gebruik van postduiven niet groot is. Voorzichtigheid bij de interpretatie lijkt dan ook aangewezen.

Hoe dan ook lijkt het vast te staan dat zowat alle enigszins "ontwikkelde" oude samenlevingen (Perzen, Grieken, Romeinen, Turken, Egyptenaren) de mogelijkheden van de postduif kenden en aanwendden.

Bogaerts oppert in zijn werk dat zonder enige twijfel ook de Hebreeuwen een dergelijk communicatiesysteem gekend moeten hebben, al geeft hij toe dat daar nergens melding wordt van gemaakt. $\left({ }^{9}\right)$

Zoals met veel zaken het geval was ging de duif als communicatiemiddel in West-Europa tijdens de Middeleeuwen een sluimerend bestaan leiden. Althans zo lijkt het. Men kan argumenteren dat het gebrek aan bronnen uit deze periode ons beeld verstoort en dat de antieke traditie gewoon verder liep. Een en ander kan echter ook te

(6) BOUQUET Y.H., syllabus etnografie, s.l., s.d., p. 2.

(7) BOGAERT F., op. Cit., p. 91. De aut eur verwijst hierbij naar een gedicht van Anakreoon, die leefde in de zesde eeuw voor onze jaartelling.

(8) WITTOUCK S., Op. Cit., p. 3.

(9) BOGAERT F., Op. Cit., p. 88.

(10) FRISCH.GAUTHIER J.; LOU. CHET P.; FRIEDMANN G., La colombophilie chez les mineurs du nord. Paris, C.N.K.S., 1961, pp. $42-43$. maken hebben met het feit dat er in West-Europa tijdens de vroege Middeleeuwen eigenlijk geen sterk gecentraliseerde staten voorkwamen. Dit had tot gevolg dat de interne communicatie binnen een rijk met een vorst zonder vaste verblijfplaats eigenlijk niet kon geschieden aan de hand van een postduivennetwerk. De basis van een dergelijk net is immers het vorstelijke duivenhok dat zich steeds in de nabijheid van het hof bevond.

Wat vaststaat is dat de antieke traditie door de "Arabieren" gekend was en overgenomen werd. $\left({ }^{10}\right)$ Illustratief hiervoor is het postduivennet dat werd opgezet in het Sultanaat van Bagdad in het jaar 1146. De bedragen die werden neergeteld voor een goed afgericht 
koppel liepen op tot 1000 goudstukken wat meteen aangeeft dat het duivenhouden niet zo maar een hobby was.

De kruisvaarders (11-13de eeuw) introduceerden de techniek van het africhten (opnieuw) in Europa, waarna de duif regelmatig functioneerde als boodschapper tussen versterkingen, militaire kampen en kloosters. ( $\left.{ }^{11}\right)$

Gedurende de Middeleeuwen was het een heerlijk recht om duiven te houden. Exacte data hieromtrent ontbreken, maar vast staat dat er, vanaf de vroege Middeleeuwen, op de "vroenhoven" steeds meer en grotere duiventorens werden opgericht. De wettelijke bepalingen (het heerlijk recht) werden vastgelegd in pachtbrieven. Daaruit blijkt dat duiven meestal in helftwinning werden gehouden: ofwel mocht de pachter de helft van de duiven voor zichzelf houden, met dien verstande dat hij de dieren in de winter voederde op eigen kosten (in de zomer moesten de duiven zelf aan de kost zien te komen), ofwel onderhield de heer zelf het duivenhok en was de mest voor de pachter. $\left({ }^{12}\right)$

Hier dient opgemerkt te worden dat gedurende de Middeleeuwen het gros van de duiven ofwel geconsumeerd werd, ofwel gehouden werd voor de mest. Dit verklaart gedeeltelijk het groot aantal koppels per toren. Immers, met een klein aantal goed afgerichte dieren, kan men meer bereiken (op gebied van communicatie) dan met een groot aantal halfwilde duiven. Dat grote aantal dieren moest bovendien gevoederd worden. En aangezien het niet de gewoonte was om duiven in de zomer te voederen (zie hoger), was een duiventoren, die een aanzienlijk aantal koppels herbergde, een ware plaag voor de omliggende (zaai) velden. Dat ook de tijdgenoot dit zo ervoer bewijst het herhaaldelijjk aanpassen van de wetgeving dienaangaande in de loop der jaren. Vanaf de 16de eeuw werd in de pachtbrieven vaak gestipuleerd dat men ofwel zijn duiven diende te voederen, ofwel zelf over een aantal bunders zaailand diende te beschikken. (13)

Onder invloed van de turbulente gebeurtenissen die de 16de eeuw kenmerkten had het heerlijk privilege veel van zijn uitstraling verloren en de feitelijke situatie was dat ook de grotere niet heerlijke bedrijven duiventorens gingen oprichten wat er dan weer toe bijdroeg dat de "duivenplaag" uitbreiding nam.
(11) FRISCH-GAUTHIER I.; LOUCHET P. ; FRIEDMANN G., Op. Cit., pp. 42-43, (12) LINDEMANS, Geschiedenis unn de landlboun in Belgiè. Deel II. Antwerpen, De Sikkel, 1952, pp. 444-446.

(13) BAERT, "Het duivenmelken en de duivenkeeten win 't verleden", Biekorf: XLV, 1939, PP. 268-269. 
Hoewel de duif dus hoofdzakelijk voor consumptiedoeleinden gehouden werd, ging de kunst van het africhten niet verloren, wel integendeel: een van de gevolgen van de grote ondekkingen (vanaf de 15de eeuw) was dat Hollandse en Portugese zeelieden gespecialiseerde postduiven binnenbrachten in Europa. Wij denken hierbij aan de "carriers" en de "bagadetten", wat overigens een verbastering is van het woord "Bagdad". ( $\left.{ }^{14}\right)$ Een van de meest sprekende historische gebeurtenissen waarin duiven een rol speelden was het beleg van Leiden en Haarlem (eind 16de eeuw). Tijdens deze belegeringen werden er duiven gebruikt om met de buitenwereld te communiceren.

Het feit dat heel wat boeren in de 17de eeuw duiven gingen houden (zie hoger) zorgde uiteindelijk voor dusdanige problemen, dat een nieuwe reglementering zich opdrong. In 1612 werd, op aandringen vanuit verschillende hoeken, een verordening uitgevaardigd door de Raad van Vlaanderen waarin gesteld werd dat ...niemand wie hy zy ten platten lande nochte elders en moghen houden noch doen houden eenighe duyven het zy in haerlieder huysen, scheure oft duyvekot daer toe ghemaeckt, die niet en hebben in proprieteyte ofte andersins besitten ofte bedryven, thien bunderen landts omtrent het hof, daer zy die duyven zullen houden, emmers niet over een quartier myls int ronde van daer ghelegen ... $\left({ }^{15}\right)$ Iedere overtreding hierop werd bestraft met een passende geldboete.

In Brabant werd een soortgelijk edict uitgevaardigd in 1613 waarin gesteld wordt dat men geen duiven mag houden tenzij... hij drij

(14) BOUQUET Y.H., Op.Cit., p. 2.

(15) BRANTS V., Receuil des ordonnances des Pays-Bas. Règne d'Albert et Isabelle. 1597-1621, Brussel, 1912 pp. 158-159. (16) THEYS C., "Duiventillen" in: Eigen schoon en de Brabander, XXXI, 1948, p. 184.

(17) GERITS T.J., “Aantekeningen over het recht om duiven te houden" in: Ons Heem, 1972, p. 184. bunderen winnende lant ter coren is hebbende in eygendom oft heuringe ... $\left.{ }^{16}\right)$

In een verordening van 6 mei 1622 van het Brugse Vrije stond dan weer dat...niemand eenige duyf-huysen ofte vlogen en houde daer boventwaelf paer duyven inwoonen, hy en sy geerft tot dertig gemeten lands, inde selve ofte inde naeste Prochie... ( ${ }^{17}$ )

Deze reglementering moet dus gezien worden als een aanpassing van de wetgeving aan de eigenlijke (versoepelde) situatie, en niet als een poging tot het in ere herstellen van een privilege of het beschermen van een bepaalde maatschappelijke klasse. 
Gedurende de 17de en de 18de eeuw zou de wetgeving verder verstrakken. Hoewel er nog lang geen sprake was van een eenvormige wetgeving werd er meestal gesleuteld aan de bepaling die handelde over het minimum aantal bunders land dat men diende te bewerken of waarvan men eigenaar moest zijn. Vaak werd men eveneens verplicht om zijn duiven binnen te houden tijdens de zaai- en oogstmaanden.

Het resultaat van deze verstrakking was dat het houden van duiven (voor welke doeleinden ook) in de 18de eeuw opnieuw een aristocratische aangelegenheid werd. Daarbij is het opmerkelijk dat gedurende deze eeuw steeds meer gegoede burgers, die niet over de minimale hoeveelheid grond beschikten, duiven gingen houden. $\left({ }^{18}\right)$

Uit deze periode dateren ook de meeste duiventorens die nu nog overeind staan. Meestal gaat het om kopieën van oudere exemplaren, die echter meestal opgesmukt zijn met meer ornamenten en fantasietjes dan de originelen.

Het zou duren tot aan de Franse revolutie alvorens er in Frankrijk definitief een einde kwam aan alle feodale voorrechten. Toen onze gewesten in 1795 door Frankrijk werden ingelijfd werd deze maatregel ook bij ons van kracht. $\left({ }^{19}\right)$ Daardoor konden nu ook particulieren/burgers duiven houden zonder dat ze het risico liepen om bekeurd te worden. Deze particulieren zouden de eerste echte beoefenaars zijn van de "duivensport" zoals we die tot op heden kennen. Daarover meer in het volgende hoofdstuk.

In de loop van de 19de eeuw werden de eerste staatsoverschrijdende netwerken opgericht. Deze ontwikkeling was onlosmakelijk verbonden met een zich als maar sneller industrialiserende maatschappij. In een dergelijke maatschappij is er nood aan snelle en frequente informatieoverdracht. Aangezien de eerste grote telegraaflijnen op het Europese vasteland slechts in gebruik werden genomen rond het midden van de 19de eeuw bleef de postduif de snelste internationale koerier.

Zelfs de beursnoteringen van de beurzen van Amsterdam, Frankfurt, Parijs en Antwerpenwerden op deze manier uitgewisseld.
(18) THEYS C., Op. Cit.. p. 185.

(19) DE SMET I. "Duiven en duivensport" in: 's Beerrje, XXIX, 1970, pp. 2425. 
De directe aanleiding hiertoe was het feit dat bankier Nathan Rotschild, dankzij zijn privé-duivenhokken, vier dagen eerder op de hoogte was van Napoleons nederlaag te Waterloo dan de Engelse regering. Daardoor kon hij grote hoeveelheden, door de oorlog in waarde gedaalde, staatswaarden kopen, die, zodra het nieuws van de nederlaag officieel werd, sterk in waarde stegen. Zo boekte hij miljoenen winst. $\left({ }^{20}\right)$

Ook persagentschappen (bv. Havas, Reuter...) en dagbladen (bv. The Times) bedienden zich van de duif om zich op een snelle manier te informeren.

Aan deze praktijk kwam vrij abrupt een einde rond het midden van de eeuw, toen, zoals reeds vermeld, de telegraaf een algemene verspreiding kende. $\left({ }^{21}\right)$

Dit was niet het geval voor de militaire berichtgeving die nog tot na de tweede wereldoorlog (gedeeltelijk) een beroep deed op postduiven. Dit verklaart meteen waarom de duivensport tot op heden onder een vrij strakke supervisie van de overheid staat.

De hoogdagen van de militaire berichtgeving met behulp van postduiven zijn te situeren tussen 1850 en 1920. Tijdens de FransDuitse oorlog werden er aan beide kanten duiven ingezet maar meest legendarisch blijft het feit dat men door middel van luchtballonnen en postduiven vanuit het omsingelde Parijs contact onderhield met het vrije Frankrijk. $\left.{ }^{22}\right)$

Binnen alle grote Europese legers ging men speciale eenheden oprichten die zich toelegden op het africhten van postduiven en het veredelen van bepaalde duivenrassen: men mag niet uit het oog verliezen dat de hedendaagse reisduif het resultaat is van een aantal gerichte kruisingen. Halfweg de 19de eeuw beschikte men nog niet over deze variëteit. Daardoor was de maximale afstand waaro-

(20) DE SMET J., Op. Cit., p. 21.

(21) De werking van de elektrische telegraaf werd op punt gest eld door Morse en Wheatstone in 1844.

(22) BERTHELOT M. (e.a.) "Pigeon" in la grande encyclopedie. Paris, S..A. de La Grande Encyclopedie, 1885-1902, p. 916. (23) DE SMET I., Op. Cit., p. 23. ver berichten konden worden overgebracht relatief klein (ca. 200 $\mathrm{km})$. Speciaal aan de africhting van militaire duiven was dat de duiven getraind werden om hun hok terug te vinden nadat het verplaatst was tot $100 \mathrm{~km}$ van zijri oorspronkelijke standplaats. $\left({ }^{23}\right)$ Wilde men verhinderen dat de vijandige legereenheden met elkaar communiceerden via duiven dan moest men beschikken over een voldoende aantal valken Bijgevolg werden in menig leger valkeniersdivisies opgericht. 
Tot aan de eerste wereldoorlog waren duiven een belangrijk communicatiemiddel bij de marine. Tijdens de eerste wereldoorlog werden ze nog ingezet op Franse, Engelse en Italiaanse oorlogsbodems.

Ook op het slagveld werden er duiven gebruikt door de Fransen en de Engelsen - de Belgische strijdkrachten beschikten tijdens de eerste wereldoorlog nog niet over een duivendivisie.

Gedurende de eerste wereldoorlog werd de duif ook ingezet bij spionageopdrachten: met behulp van een miniatuurcamera, bevestigd aan de poten van een duif, konden luchtfoto's van het vijandig gebied gemaakt worden.

Het is vooral in die zin dat de reisduif ook nog tijdens de tweede wereldoorlog werd ingezet. Zo telde de duivendienst van het Amerikaanse leger 3000 man en 54000 getrainde duiven. $\left({ }^{24}\right)$

Het spreekt voor zich dat de bezetter zeer wantrouwig was tegenover de duiven van de Belgische duivenliefhebbers. Concreet ordonneerde men in 1914 de opsluiting van de dieren (m.a.w. een spelverbod) en in 1915 de opruiming van de gehele duivenstapel wat een ernstige klap betekende voor de liefhebberij. Een zelfde scenario deed zich voor bij aanvang van de tweede wereldoorlog met dat verschil dat alle duiven in 1944 verzameld werden in een centraal duivenhok in Brussel: strikt genomen werden de duiven dus niet afgemaakt, maar in werkelijkheid overleefden slechts $25 \%$ van alle duiven het verplichte logement... $\left({ }^{25}\right)$

\section{Biologische zijsprong}

Alvorens het wel en wee van het "moderne" duivenspel te bespreken lijjkt het me zinvol om even dieper in te gaan op enkele biologische/fysiologische kenmerken van de duif omdat deze nu eenmaal de basis vormen van dat spel: het is immers dank zij het uitzonderlijke oriëntatievermogen van het dier dat het duivenspel beoefend kan worden.

\section{De anatomie}

Een eerste basisgegeven is dat een duif in verhouding tot haar gewicht (ca. 400-480 g) een groot volume heeft. ${ }^{26}$ ) Duiven zijn dus verhoudingsgewijs lichte dieren. Deze eigenschap heeft een gunstige invloed op het vliegvermogen en het daaraan gekoppelde uit- 
De oorzaak van het geringe gewicht is een combinatie van het voorkomen van luchtzakken, die bij inademen uitzetten en lucht in de longen persen, met het feit dat een deel van het geraamte (o.a. de vleugelgedeelten) van een duif hol is. Deze laatste eigenschap heeft echter wel een negatieve invloed op de stevigheid van dat skelet. Daarenboven blijkt een vleugelbreuk veel moeilijker te genezen dan een pootbreuk. Een vleugelbreuk betekent praktisch steeds het vroegtijdig einde van de reisduifcarriëre. In het beste geval worden dergelijke duiven door de liefhebber verder gehouden als kweekduif, in het slechtste geval belanden ze op tafel...

Een tweede element dat een invloed heeft op zowel het gewicht, als het uithoudingsvermogen en de vliegsnelheid, is de spiermassa in het algemeen en meer in het bijzonder de spiermassa van de grote borstspier, die de neerwaartse vleugelbeweging teweegbrengt. $\left({ }^{27}\right)$

Deze grote spier is bij reisduiven bijzonder goed ontwikkeld (deze spier alleen al is goed voor ongeveer de helft van de totale spiermassa). Dit is voor een groot deel het gevolg van een selectieve kruisingspolitiek die werd aangehouden door de eerste "moderne" duivenmelkers in de late $18 \mathrm{de}$ en vroege 19de eeuw. Door hun zoektocht naar duivensoorten met goede vliegeigenschappen creëerden ze immers de moderne duivenrassen. Een van de kenmerken van deze laatsten is onmiskenbaar de goed ontwikkelde borstspier.

Bij een duivenkeuring wordt er dan ook veel aandacht besteed aan het betasten van de borstspier, die volgens de liefhebbers zo lang en zo soepel mogelijk moet zijn.

Dat de borstspier als een cruciaal onderdeel van de duif werd en wordt ervaren blijkt ook uit het feit dat in het melkersjargon typische termen bestaan om de spier of de weerstand van de spier te beschrijven.

Een derde en laatste anatomische en voor het spel bepalende factor is het verenkleed. Niet zozeer omdat duiven een uitzonderlijk verendek zouden hebben, maar wel omdat een duif jaarlijks een deel van haar veren afstoot en vernieuwt. Het ander deel van de

(27) HERMANS J., Postduiven. Utr echt; Antwerpen, Het Spectrum, 1985, pp. 58 59. veren wordt vernieuwd over een periode van enkele jaren. Dat af stoten of "ruien" gebeurt in de maanden augustus tot september. In deze periode worden de slag-, broek- en staartpennen volgens 
een welbepaald schema vernieuwd. In volle ruiperiode is het niet raadzaam om z'n duiven te laten deelnemen aan wedstrijden omdat het vliegvermogen enigszins is aangetast, maar vooral omdat het ruien een pijn veroorzaakt die vergelijkbaar is met een tandwissel bij zoogdieren. ${ }^{28}$ ) In de literatuur zijn bladzijden gevuld met de vraag naar het tijdstip waarop men de duiven beter binnen houdt en hoe men de rui kan beïnvloeden (door bijvoorbeeld het hok te verduisteren of extra te verlichten) maar algemeen wordt aangenomen dat men bij aanvang van de rui van de vijfde slagpen zijn duiven niet meer laat vliegen en dat men het ruiproces zo weinig mogelijk mag beïnvloeden. ${ }^{29}$ )

\section{Het oriëntatievermogen}

Jan Hermans merkt in zijn "Postduiven" $\left.{ }^{30}\right)$ terecht op dat "oriëntatievermogen" een ongelukkig gekozen term is omdat een duif niet alleen in staat is om haar positie te bepalen maar eveneens in staat is een koers te bepalen: namelijk deze richting hok. Hij heeft het liever over het "navigatievermogen", wat te verdedigen valt, al opteert hij in z'n exposé toch voor de term "oriëntatievermogen" omdat deze nu eenmaal sterker ingeburgerd is. Wij zullen eveneens deze laatste term gebruiken.

Hoe men het ook draait of keert, het oriëntatievermogen van de duif is en blijft de basis van de duivensport. Het is een aangeboren eigenschap die volgens sommigen - hier lopen de meningen uiteen - verbeterd kan worden door een doorgedreven "training".

De vraag naar de werking van het oriëntatievermogen is een vraag die wetenschappers tot op vandaag bezighoudt. Eigenlijk is men er nog steeds niet volledig achter en kunnen bepaalde eigenschappen nog steeds niet volledig wetenschappelijk verklaard worden.

Vast staat dat een duif over een inwendige klok beschikt die $15^{\circ}$ per uur verloopt. Anders gezegd: in één dag maakt deze klok juist één omwenteling. Dit doet de zon ook waardoor deze ten opzichte van die inwendige klok als vast richtpunt kan fungeren. Dit verklaart veel maar niet alles. Een duif is immers in staat om zich ook bij bewolkt weer te oriënteren.

Een verklaring hiervoor wordt gezocht bij de overgevoeligheid van de duif voor veranderingen in aardmagnetisme, de verandering van breedtegraad - of de afwijking van de breedtegraad van deze waar-
(28) BOUQUET Y.H. Op. Cir.. p. 26 (29) zic o.a. QUICK R., A B C irsu de duivenmelker. Zele, D.A.P. Reinaert uitganven. 1980, pp. 8.3-90.

(30) HERMANS I., Op. Cir., IM. 194-196. 
op het hok zich bevindt en de mogelijkheid om weerkaatst gepolariseerd licht te capteren zoals ook werksterbijen dat kunnen. $\left({ }^{31}\right)$ Verder zouden duiven zich eveneens kunnen oriënteren op de poolster, hoewel ze, zoals gezegd, zelden 's nachts vliegen. Het feit dat er op het zuidelijk halfrond praktisch geen duivenvluchten voorkomen wordt soms verklaard door het verschil in sterrenhemel in noord en zuid.

Verder beschikt een duif ook over een algemeen goed ontwikkeld zicht (het opvangbare spectrum reikt tot aan het ultraviolet) en een goed ontwikkelde reukzin. Vooral dat laatste is uitzonderlijk bij vogels en kan helpen bij het herkennen van de omgeving van het hok (denken we hierbij aan de geur van landbouwgewassen, meststoffen... in de omgeving van het hok). Ook verschillen in luchtdruk kunnen worden waargenomen.

Een heel merkwaardige vaststelling tot slot is het feit dat duiven die op honderden kilometers afstand van elkaar werden gelost, de laatste kilometers exact op dezelfde manier afleggen, zonder ook maar een fractie van het traject af te wijken. Verklaringen hiervoor zijn nog steeds niet gevonden.

\section{Het voortplantingsgedrag}

Duiven zijn in principe monogaam en leven in koppels. De vruchtbare periode bedraagt zowat vier jaar en begint wanneer de duiven vier en een halve maand oud zijn. $\left.{ }^{(32}\right)$

Per nest worden, 15 dagen na het paren, twee eieren gelegd en de broedtijd bedraagt 17 tot 18 dagen.

Jongen komen naakt en blind uit het ei en zijn hulpbehoevend, dus zijn het nestblijvers. Na drie weken worden de jongen van de ouders gescheiden, zodat de ouders een nieuw broedsel kunnen voortbrengen. Op deze manier kan een koppel per seizoen 3 à 4 broedsels voortbrengen. $\left.{ }^{33}\right)$

\section{De voeding}

(31) BOUQUET Y.H., Op. Cit., pp. 23 24.

(32) VAN SEVEREN A., Syllabus etnografie. s. l., s. n., s. d., p. 3.
...De duif is een zaadetende vogel, hebbende den reuk weinig ontwikkeld maar integendeel eenen zeer fijnen smaak. Men kan hem gewend maken aan allerlei voedsel, zooals brood, gekookte aardappelen, enz., doch dit voedsel dient beter voor Huis- dan voor Reisduiven... $\left(^{34}\right)$ 
Reeds in de begindagen van de duivensport (bovenstaand citaat dateert uit 1891) was men er zich van bewust dat de voeding van de duiven prestatiebepalend is. De basisbestanddelen van het duivenvoer waren, op het einde van de 19de eeuw, kleine veldboon, vitse en platte erwt. Tegelijk wees Wittouck toen al op het nut van een aangepast menu in de winter, de kweektijd, de speeltijd en tijdens de rui. $\left({ }^{35}\right)$

Voor elk seizoen zijn er tegenwoordig aangepaste voedselmengsels op de markt die voldoende koolhydraten, eiwitten en vetten bevatten en daarnaast ook nog rijk zijn aan mineralen, vitaminen en sporenelementen (kobalt, jodium en fosfor). ${ }^{(36}$ ) De huidige basisbestanddelen van het voedsel zijn: tarwe, rogge, gerst, haver, maïs, bonen, erwten, wikke, hennepzaad, lijnzaad, koolzaad, sorghum en gierst.

Omdat duiven geen tanden hebben die het maalwerk voor hun rekening kunnen nemen is het aangewezen dat er steeds een hoeveelheid grit bij het voedsel staat. Grit is eigenlijk niet anders dan fijn steengruis, gebroken schelpen of kalk.

Grit zorgt er bovendien voor dat duivinnen eieren leggen met sterke schalen.

\section{Het spel}

In deze paragraaf zal het duivenspel - zoals het tegenwoordig nog wordt gespeeld - van naderbij bekeken en besproken worden. Een eerste vraag die zich daarbij opdringt is de vraag naar een goede definitie of omschrijving van het spel. Daarbij werd het duivenspel met Frisch-Gauthier omschreven als: "la préparation et l'organisation des courses de pigeon-voyageurs sur des distances variant selon les cas de 30 à $1000 \mathrm{~km}$, parfois d'avantage". ${ }^{\left({ }^{37}\right)}$

\section{Oorsprong en verspreiding}

Hoewel er tegenwoordig wereldwijd "met de duiven wordt gespeeld" $\left.{ }^{38}\right)$ staat de wieg van de sport in het huidige België.

Het spel ontwikkelde zich min of meer synchroon in een aantal Belgische steden in het begin van de 19de eeuw.

Een eerste kerngebied was Antwerpen. Baron Ulens en zijn knecht André Bernaert zouden er in die mate duiven veredeld hebben dat
(33) VAN SEVEREN A., Op. Cit., p. 4.

(34) WITTOUCK S., Op. Cit., p. 45.

(35) WITTOUCK S., Op. Cit., p. 46.

(36) HERMANS J., Op. Cit., p. 98.

(37) FRISCH-GAUTHIER J.; LOUCHET

P.; FRIEDMANN G., La colombophilie chez les mineurs du Nord. Paris, C.N.R.S., 1961, p. 48.

(38) Frisch-Gaultier, Louchet en Friedmann vermelden op 227 volgende landen: Belgiè, Frankrijk, Nederland, Luxemburg, Het Verenigd Koninkrijk. Denemarken, Zweden, Noorwegen, Spanje, Zwitserland, Italiě, lex-] Tjeshoslowakije, Polen, Cuba, Ierland, De Verenigde Staten, Duitsland, Roemeniè, linpili. 
(39) Welkombrochure Belgische Duivenliefhebbersbond. s.l., s.n., s.d., p. 4.

(40) "Wedstrijden met duiven" in: Algemeene Konst en Letterbode. 1816, p. 109. (40) "Wedstrijden met duiven" in: Algemeene Konst en Letterbode. 1816, p.109.

(41) "Duivenvluchten" in: Ons heem, XXVI, 1972, pp. 204-205.

(42) Bv. de kennismakingsbrochure van de koninklijke Belgische Duivenliefhebbersbond.

(43) BOGAERTS F., Histoire civile et religieuse de la colombe. Anvers, Imprimerie de J.-E. Buschmann, 1847, pp. 270-271. (44) ldem. er frequent wedstrijden georganiseerd konden worden. $\left({ }^{39}\right)$ Naar alle waarschijnlijkheid gebeurde dit niet louter uit liefde voor de sport, maar speelden er ook economische belangen omdat duiven in de eerste decennia van de 19de eeuw nog functioneerden als beursberichtgevers. Dit zou meteen kunnen verklaren waarom een baron zich met de duivenkweek inliet.

Het tijdschrift Algemeene Konst en Letterbode maakte - onder de rubriek "Merkwaardigheden derNatuur" - in 1816 melding van een vlucht uit Londen die werd georganiseerd door een aantal Antwerpse liefhebbers. $\left({ }^{40}\right)$ De ingezette duiven moesten binnen de drie dagen na het lossen aankomen om geklasseerd te worden en aanspraak te kunnen maken op een van de vier materiële prijzen. Slechts één duif slaagde er in binnen de twee dagen aan te komen, van de andere duiven nam men aan dat ze "verdoold" waren. Men kan zich afvragen of er hier al sprake was van een georganiseerde liefhebberij of dat we hier te maken hebben met een aantal waaghalzen die zich aan een experiment waagden waarvan ze op voorhand wisten dat de kans op slagen eerder gering was.

Uit de lage vliegsnelheid en het verloren vliegen van het gros van de duiven blijkt alvast dat de dieren nog niet erg veredeld waren. Het feit dat een dergelijk tijdschrift melding maakt van een wedvlucht doet besluiten dat een dergelijke vlucht toen nog een unicum was. Maar er is iets aan de hand met het bericht: het duikt ook op in Ons Heem (1972), waarbij de auteur zich beroept op het privé-archief van de familie Leys, waaruit blijkt dat de winnaar van de wedstrijd een Gentse duif was, nl. deze van de heer Leys zelf, die in Gent woonde. De overwinning werd dan ook uitbundig gevierd in het Gentse café "'s Lands Welvaren". Uit dat archief blijkt verder dat er ook vanuit Brugge vluchten op Londen werden georganiseerd, zij het dat deze vooral tot doel hadden de Napoleontische continentale blokkade te omzeilen. $\left({ }^{41}\right)$

Dit doet vraagtekens rijzen bij de vermeende autonomie van de kerngebieden die door bepaalde bronnen wordt gepostuleerd. $\left({ }^{42}\right)$ Hoedanook zouden er in Antwerpen in 1828 niet meer dan 7 à 8 maatschappijen geweest zijn die elk ca. 25 leden telden. In 1847 telde de stad reeds 30 maatschappijen. $\left({ }^{43}\right)$ Er van uitgaand dat de gemiddelde melker 12 koppels duiven had resulteert dit in een totaal duivenbestand van ca. 18000 duiven, $\left({ }^{44}\right)$ wat aanzienlijk is. 
Een tweede gebied waar het duivenspel zich ontwikkelde is de Luikse regio. Reeds in 1806 werden er in Parijs duiven van Luikse duivenliefhebbers gelost. Tevens heeft men weet van een prijsvlucht uit 1810 op Lyon. $\left({ }^{45}\right)$ Dit zou er op kunnen wijzen dat het spel zich iets vroeger ontwikkelde in het Luikse, al is enige voorzichtigheid hier op z'n plaats.

Ook te Gent en te Brussel $\left({ }^{46}\right)$ werden er reeds in het begin van de 19de eeuw wedstrijden georganiseerd, zij het een fractie later dan het in Antwerpen en Luik het geval was. De richtdatum zou hier 1820 zijn. $\left({ }^{47}\right)$

Hoewel, reeds in 1815 vloog een duif van Tours naar Gent, in 1826 werd een wedstrijd vanuit Parijs ingericht en in 1830 werden Gentse duiven gelost in Lyon. $\left.{ }^{48}\right)$

Ten slotte zouden er ook te Verviers, te Namen en te Lier, in een vroeg stadium (1815-1820), kernen van duivenmelkers ontstaan zijn. Boegbeelden van deze kernen waren Alexandre Hansenne uit Verviers en Karel Wegge uit Lier. $\left({ }^{49}\right)$

Een opvallende vaststelling hierbij is dat de duivensport, in tegenstelling tot de duivenhouderij uit het Ancien Régime, gekenmerkt wordt door een vrij uitgesproken stedelijk karakter, of op z'n minst gerelateerd is aan grote industriebekkens. Dit wekt de indruk dat er een verband bestaat tussen de beoefening van de sport en de opgang van de stedelijke arbeidersklasse.

Uit de literatuur blijkt echter dat de sport in de beginjaren vooral werd beoefend door de gegoede stedelijke klasse. De verklaring daarvoor is tweeledig. Enerzijds hadden bepaalde lieden er, zoals reeds even aangehaald, zakelijk belang bij om over een goed stel duiven te beschikken met het oog op vlotte communicatie-overdracht. Voor hen was het spel allicht een aangename bijkomstigheid. Anderzijds was de burgerij de enige groep die de hoge verzendingskosten kon bekostigen. Men mag immers niet uit het oog verliezen dat de (goedkope) massatransportmiddelen nog niet of nauwelijks bestonden. Duiven werden aanvankelijk met paard en kar vervoerd. Deze methode bleek uiteindelijk weinig voldoening te schenken. Later werden de duiven door voetgangers, die manden met 40 à 50 duiven op de rug droegen (!), naar de losplaatsen
(45) DE SMET I., "Duiven en duivensport" in: 't Beertie, XXIX, 1970, pp. 2425.

(46) WITTOUCK S., De duivenliefluebberij. Wetenschappelijk hamdboek, Gent, Stepman, 1891, pp.4-8.

(47) Idem.

(48) DE SMET I., "Duiven en duivensport" in: 't Beertie, XXIX, 1970, pp. 24. 25.

(49) IVellomsbrochure wan de Belgische

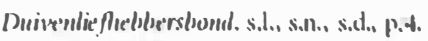


Wedstrijdduiven zendklaar. In de beginjaren werd de duivensport vooral beoefend door de gegoede stedelijke klasse ... (Foto beeldenarchief Het Huis van Alijn)

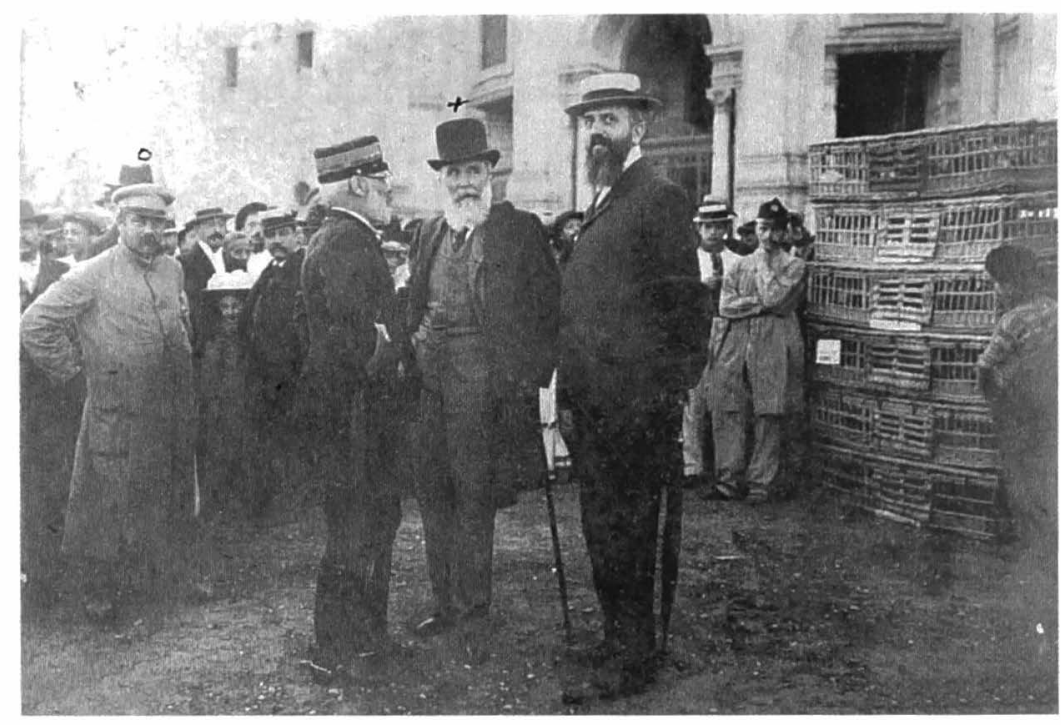

gedragen. $\left({ }^{50}\right)$ Een tocht van Hoei naar Orléans nam op deze wijze negen volle dagen in beslag en was bijgevolg duur. $\left({ }^{51}\right)$

Toen arbeiders eveneens het duivenspel gingen beofenen waren deze genoodzaakt om korteafstandsvluchten te organiseren. Aldus werden er in 1815 ten behoeve van de Gentse arbeiders prijsvluchten uit Antwerpen, Brugge en Rijsel georganiseerd.

Te Brussel werd in 1826 een maatschappij opgericht door werklieden. Het zou echter tot 1838 duren vooraleer deze vereniging regelmatig wedstrijden kon organiseren die verder reikten dan de kerktoren. $\left.{ }^{(52}\right)$

In West-Vlaanderen en Limburg kende de duivensport pas later een echte doorbraak. Als richtinggevende datum kan men hier 1845 naar voor schuiven. Dit wil niet zeggen dat het duivenspel er compleet onbekend was, alleen werd het nog niet op grote schaal beoefend.

\section{De materiële vereisten}

Wil men de duivensport beoef enen dan zal men moeten investeren in een basisuitrusting. Eerst en vooral is er het hok. Om deel te nemen aan duivenwedstrijden moet men over een aantal duiven beschikken. De belangrijkste criteria waaraan een goede huisvesting moet voldoen zijn de volgende: een hok moet ruim genoeg zijn, voldoende droog zijn, het moet eveneens regelmatig schoon-
(51) Idem.

(52) Idem. 
gemaakt worden en het moet voldoende ventilatiemogelijkheden hebben. Ook een voldoende lichtinval wordt door de dieren op prijs gesteld. $\left({ }^{53}\right)$

Wanneer er aan één van deze criteria niet of niet voldoende wordt voldaan is de kans reëel dat de duivenpopulatie getroffen wordt door ziekten en epidemieën wat de wedstrijdresultaten uiteraard niet ten goede komt.

De meest geschikte ruimten bevinden zich dus niet direct op de begane grond - zo vermijdt men vochtproblemen - en zijn met het oog op een goede ventilatie toegedekt met een pannendak. De meeste hokken zijn dan ook op palen geplaatst of bevinden zich op een zolder. Het nadeel van deze laatste is dat ze niet zo praktisch zijn omdat men constant met voedsel en mest op en af moet, maar meestal zijn er minder vochtproblemen. $\left({ }^{54}\right)$

De ideale oriëntatie van een hok is deze waarbij de openingen gericht zijn op het zuiden, het oosten of het zuidoosten $\left({ }^{55}\right.$ ) (maximale lichtinval). Een opening is voorzien van een 'valplank'. Dit is een plank waarop de duiven, die terugkomen van een vlucht, landen alvorens ze binnenkomen. In de opening kan men eventueel een 'spoetnik' of kijker plaatsen, wat eigenlijk een soort kooi is die in de vensteropening hangt, met een afsluitbare opening naar buiten. In de spoetnik kunnen jonge duiven de omgeving verkennen zonder dat ze het hok kunnen verlaten.

Meestal is een hok verder ingedeeld in een aantal nesthokjes en beschikt het verder over een aantal zitplankjes. Afhankelijk van de gevolgde speeltechniek (zie verder) kan het hok eventueel beschikken over aparte, van tralies voorziene, afsluitbare hokjes voor de koppels (weduwschap) of over hokjes met aparte in- en uitgang (kotjesspel). $\left({ }^{56}\right)$ De nethokjes moeten voldoende ruim zijn (ca. 50 * $50 * 50 \mathrm{~cm}$ ) en bovendien is het aangewezen om de nesthokjes verder te voorzien van een tussenschot zodat ieder koppel als het ware over twee kamertjes beschikt. Het voordeel van een dergelijke onderverdeling is dat er bij duiven, die kort nadat de eerste jongen uit het ei kropen al broeden op een volgend nest, minder jongen verloren gaan doordat de zorg over de jongen op deze manier beter verdeeld wordt. ${ }^{57}$ ) In een nesthok plaatst men bij voorkeur twee nestschalen in aardewerk, het nesthok zelf is bij voorkeur in vurenhout gemakt omdat dit een houtsoort is waarin weinig ongedierte
(53) BAETEN E., Succes in de duivensport. Antiverpen-Apeldoorn, Maklu, 1986, pp. 33-35.

(54) QUICK R., Duivensport totual. Gent, Het Volk, 1976, pp. 239-242.

(55) WITTOUCK S., Op. Cir., pp. $28 \cdot 29$. (56) HERMANS 1., Postduinen. UtrechtAntwerpen, Het Spectrum, 1985, ß. 201. (57) Idem. 
Een duivenmelker voedert zijn duiven in gezelschap van de duivenmelkersvereniging. (Foto beeldenarchief Het Huis van Alijn)

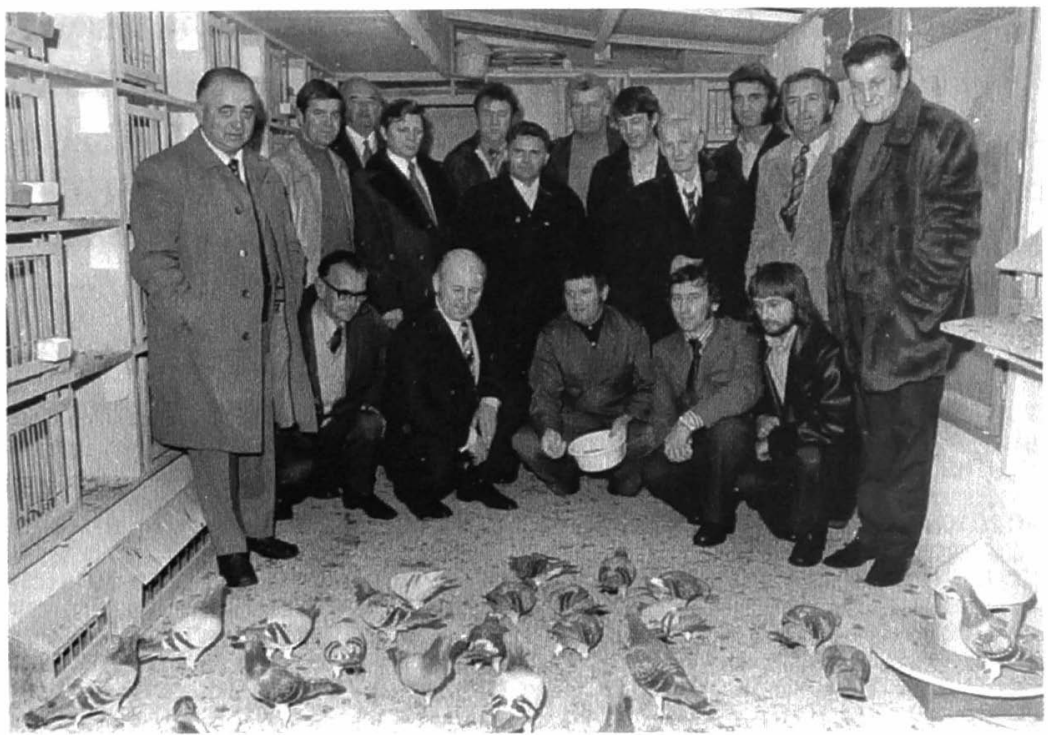

nestelt.

Eventueel kan men naast het duivenhok nog een volière bouwen, maar dan moet men er wel op letten dat deze over een verharde bodem beschikt (bv. beton). Is dat niet het geval, dan is de kans groot dat de volière in de kortste keren een broeihaard van ziekten en ongedierte wordt. $\left({ }^{58}\right)$

Het spreekt vanzelf dat het duivenhok eveneens voorzien is van de nodige voeder- en drinkinstallaties.

Omdat in het duivenspel tijd en snelheid een vooraanstaande rol spelen kan de duivenmelker een aantal supplementaire verbeteringen aanbrengen aan het hok. Zo kan hij bij wijze van voorbeeld het hok uitrusten met een automatische meldinstallatie. Tegenwoordig zijn dat meestal elektronische toestelletjes die verwant zijn aan bewegingsmelders zoals deze gebruikt worden in alarmsystemen, maar ook in vroegere tijden waren er inventieve melkers die mechanische meldinstallaties in elkaar knutselden. Raymond Verschoore was er zo één: deze horlogemaker uit Tielt gebruikte zijn vakkennis om reeds in 1873 een 'zelfwekker' in elkaar te steken

(58) QUICK R., Duivensport totaal. Het Volk, 1976, p. 240.

(s9) WITTOUCK S., Op. Cit., pp. 37-38. waarbij de valplank scharnierde en via een aantal katrollen en touwtjes verbonden was met een mechanische wekker. $\left.{ }^{(59}\right)$ Speltechnisch is het van belang dat een hok niet te groot is omdat 
de duivenmelker de binnenkomende duif zo snel mogelijk te pakken moet krijgen om de thuiskomst te 'constateren'. Daarom is het aangewezen om in een zolderhok op stahoogte een horizontale afscheiding aan te brengen die, met het oog op de ventilatie, liefst halfopen is (bv. een traliewerk).

Wil men deelnemen aan wedstrijden dan moet de exacte positie van het hok gekend zijn: de klassering van de reisduiven wordt immer gemakt aan de hand van de gemiddelde vliegsnelheid. Deze snelheid is niets minder dan de door de duif afgelegde afstand gedeeld door de tijd die de vlucht in beslag neemt. De coördinaten van een hok worden tegenwoordig door landmeters bepaald, vroeger werd daarvoor meestal de dorpsonderwijzer of een andere 'intellectueel' ingeschakeld. $\left({ }^{60}\right)$

\section{De manden of korven}

Wedstrijdduiven worden verzameld op bepaalde punten, de zogeheten inkorvingslokalen, om daarna verzonden te worden naar de lossingsplaats. Iedere duivenmelker die wil deelnemen aan een wedstrijd moet bijgevolg beschikken over één of meerdere manden om z'n duiven naar het wedstrijdlokaal te brengen. Vroeger werden deze manden vervaardigd uit blanke wissen, de luxemodellen hadden een bodem die bekleed was. $\left({ }^{61}\right)$ Tegenwoordig zijn er kunststof- en aluminiummodellen op de markt. Een goede reismand moet licht en handelbaar zijn en daarenboven is ze liefst voorzien van tussenschotten, zodat de geslachten gescheiden getransporteerd kunnen worden. Idealiter bevinden de deurtjes zich aan de bovenkant. ${ }^{62}$ )

Eenmaal in het lokaal aangekomen worden de duiven overgeladen in verzendingsmanden die eigendom zijn van de verzendingsmaatschappijen. Als de verzending per trein of per vrachtwagen gebeurt, gebruikt men rieten manden. Wanneer er bij de verzending gebruik gemaakt wordt van de zogeheten 'duivencontainers', dan worden de duiven in aluminiummanden ingekorfd. $\left({ }^{63}\right)$

Afsluitend nog dit: reismanden waren tijdens het interbellum vaak te winnen als bijzondere prijs in natura. Dit geldt ook voor constatatieklokken, maar deze worden hierna besproken.
(60) Gesprek Luc Devlieghere.

(61) In diverse duivenkranten vindt men advertenties die dergelijke manden aunprijzen.

(62) HERMANS I., Op. Cit.. pp. 205-20\%. (63) Iilem. 
(64) Volgens De Smet J. (pp. 26-27) werden loopjongens ingezet die elkaar eventueel aflosten. Deze praktijk werd mondeling bevestigd door Luc Devlieghere. (65) Wittouck S. geeft in z'n boek "De Duivenliefhebberij" uit 1891 op bladzijde 264 en volgende een overzicht van de belangrijkste uitvinders van constateurs, 7onder evenwel exacte data te vermelden. Nog volgens deze auteur is de uitvinder van de gummiring een zekcre Rosoor uit Tourcoin. Ook hier ontbreekt een exacte datum.

(66) Althans in Belgic, in Nederland mag men de ring rechtst reeks in de constateur steken.

(67) Idem.

\section{De constatatieklok}

De essentie van het duivenspel is doorheen de tijden niet veranderd: de geloste duiven moeten zo snel mogelijk naar hun hok terugkeren en de duif die de hoogste gemiddelde vliegsnelheid heeft wint het concours. Om deze gemiddelde snelheid te kunnen berekenen is uiteraard het exacte uur van aankomst van belang. Tegenwoordig wordt dat uur vastgelegd met behulp van een constatatieklok of 'constateur' maar dit is niet altijd zo geweest.

Aanvankelijk vormden de aangekomen duiven zelf het levende bewijs: de duivenmelker moest zijn binnengekomen of 'gevallen' duif gaan tonen in het lokaal en het uur van aankomst in het duivenlokaal werd als doorslaggevend beschouwd. De literatuur blijft het antwoord op de vraag hoelang deze praktijk werd toegepast schuldig maar het is duidelijk dat deze constatatiemethode enkel mogelijk is wanneer de deelnemende duivenmelkers a) in de buurt van het lokaal woonden (loopafstand) $\left({ }^{64}\right)$, b) het aantal deelnemers gering was en - wilde men de kans op vervalsing door het verwisselen van duiven beperken - c) de duivenmelker slechts over een miniem aantal duiven beschikte (enkele koppels?)

Iets voor de eeuwwisseling werden twee innoverende uitvindingen gedaan die de constatatie aanzienlijk vereenvoudigden: de gummiring en de constatatieklok. $\left({ }^{65}\right)$

Op de gummiring (of wedstrijdring) bevond zich een uniek nummer. Voortaan zou elke duif voor de wedstrijd een dergelijke ring om krijgen. Om bij aankomst eventuele twijfel omtrent de identificatie van de duif te voorkomen krijgt de duivenmelker bij het ringen per ring een vignetje of 'souche' waarop eveneens het ringnummer vermeld staat, deze souche is tegelijk het bewijs van inkorving.

Van zodra de duif valt wordt de ring van rond de poot van het dier verwijderd en in een koperen hulsje of 'potje' gestopt. $\left({ }^{66}\right)$ Dit hulsje wordt vervolgens in de constatatieklok gestopt en het is deze handeling die de eigenlijke tijdsvaststelling verwezenlijkt: met behulp van een sleutel wordt het 'ringenrad' of het 'ronsel' in beweging gezet, wat een exacte tijdsnotering op een papierstrook teweegbrengt $\left({ }^{67}\right)$ (tot op de seconde nauwkeurig). Een constatatieklok is dus eigenlijk niets anders dan een mechanisch of (tegenwoordig) elektronisch uurwerk in een verzegelde kast, waaraan een druk- of 
markeermechanisme verbonden is. Om geknoei tegen te gaan worden de klokken van constateurs voor de wedstrijd gelijk gezet (met de moederklok van de maatschappij) en worden de constateurs gelood. Vooral in vroegere tijden - het begin van de eeuw - waren niet alle uurwerken even klokvast. Eventueel voor- of achterlopen van een klok wordt na de wedstrijd gecorrigeerd door de door de constateur aangegeven tijd te vergelijken met de tijd van de moederklok.

$\mathrm{Nu}$ waren constateurs behoorlijk dure toestellen (eigenlijk zijn ze dat nog steeds) die buiten het budget van menig melker vielen. De eerste constateurs werden dan ook door de duivenmaatschappijen aangekocht, die ze verhuurden aan hun leden. Ook deze huurgelden waren - rond de eeuwwisseling - behoorlijk hoog: zowat het equivalent van een half arbeidersdagloon. $\left({ }^{68}\right)$ Constateurs werden in een overgangsperiode dan ook vaak per straat verhuurd. $\left({ }^{69}\right)$ Uiteindelijk zou het tot het interbellum duren alvorens iedereen een constateur aan huis geleverd kreeg (door de duivenmaatschappijen). Over het bezit van constateurs tijdens het interbellum bestaan uiteraard geen cijfers, maar de veelvuldige advertenties voor dergelijke klokken in de gespecialiseerde bladen zou erop kunnen wijzen dat de prijs ervan daalde.

\section{Indeling naar afstand}

Traditioneel deelt men de wedstrijden in in vier categorieën: de snelheidsvluchten, de halve fond, de lichte fond en de zware fond. Elke klasse vereist een aangepast type duif. Dat dergelijke aangepaste typen - of meest geschikte soorten - bestaan is een gevolg van gerichte kweekprogramma's die in vele gevallen het werk waren (en nog steeds zijn) van generaties liefhebbers. Het logisch gevolg van een dergelijke kweekstrategie is dat 'dé duivenmelker' eigenlijk niet meer bestaat: men gaat zich meer en meer toeleggen op één enkele of op hooguit twee disciplines. Dit is ooit anders geweest: vroeger waagde iedere liefhebber zich wel eens aan een vlucht op Barcelona of een aanverwante glorierijke vlucht. $\left({ }^{70}\right)$

Tegenwoordig ziet de situatie er als volgt uit: $17 \%$ speelt fond, 38\% speelt halve fond en $45 \%$ spelen op snelheid. $\left({ }^{71}\right)$

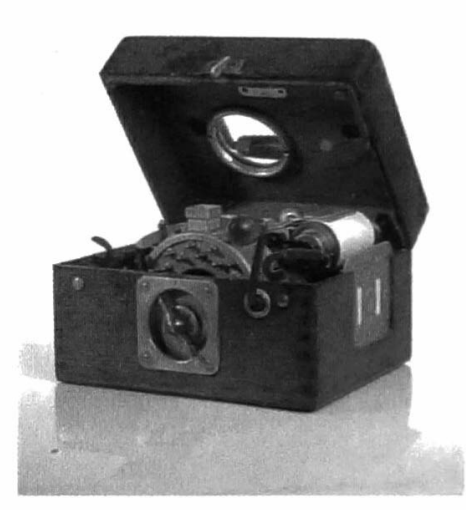

Een constateur.

(Beeldarchief Het Huis van Alijn)
(68) DE SMET I., Op. Cit., p. 27. (69) Waarbij, volgens Luc Devlieghere, de constateur al eens onevenredig dicht in de buurt van het notariaat of de pastorij werd geplaiatst.

(70) MALFAIT A., Bewust dnivenmelken. Antwerpen-Apcldoorn, Maklu, 1994, p. 176.

(71) MALFAIT A., Op. Cir. p. 177. 
(72) BOUQUET Y.H., Op. Cit., p. 17.

(73) HERMANS J., Op. Cit., pp. 190-191.

(74) BAETEN E., Op. Cit., pp. 17-18.

(75) VAN ZEVEREN A., Onuitgegeven syllabus etnografie, versie 1999, s.l., s. n., s. d., p. 5.

(76) Volgens Luc Devlieghere werden er zelfs occasionele kerstvluchten georganiceerd maar daarvan hebben wij geen vermeldingen terug gevonden.

(77) HERMANS J., Op. Cit., Pp. 190-191. (78) VAN ZEVEREN A., Op. Cit., p. 5.

\section{De snelheidsvluchten}

Snelheidsvluchten heten in jargon 'de vitesse'. Het betreft vluchten van korte afstand, waarbij de duiven een afstand afleggen van 50 à $250 \mathrm{~km} .\left(^{72}\right)$ Voorbeelden van dergelijke vluchten zijn (afstanden tot Gent): Clermont (205 km), Compiègne (190 km), Laon (163 km), Noyon (169 km), Quevy (76 km), Quiévrain (69 km), St.-Quentin $(135 \mathrm{~km}) \ldots\left(^{73}\right)$

Op snelheid wordt er bij voorkeur gespeeld met duiven die explosief en atletisch zijn en weinig van de rechte lijn afwijken. Door de korte afstand is de vliegsnelheid van de deelnemende duiven (ook wel de klad genoemd) ongeveer gelijk. Het is de snelheid van binnenkomen die het verschil makkt. Bij de vitesse speelt de behendigheid van de duivenmelker eveneens een rol: hij moet goed met zijn duiven overweg kunnen, de dieren geen angst inboezemen, ze weten te lokken en de wedstrijdring snel van de duivenpoot weten te verwijderen. Bovendien moet hij, volgens sommigen, de spelvorm (weduwschap of niet, zie verder) weten te variëren om de dieren gemotiveerd te houden. $\left({ }^{74}\right)$

Gezien de korte duur (maximaal enkele uren) van dergelijke wedstrijden, verloopt de recuperatie van de dieren snel. Daardoor kan men ze, tijdens het vliegseizoen, praktisch iedere week meegeven. Dat vliegseizoen start, bij het vitessespel, in maart en loopt tot eind september, waarbij het meestal zo is dat men tot eind mei met oude duiven speelt, waarna het spel met de jonge duiven wordt voortgezet. $\left({ }^{75}\right)$ Hier moet echter worden opgemerkt dat het vliegseizoen en dat geldt voor alle afstanden - tijdens het interbellum, langer duurde: men speelde doorgaans tot eind oktober of nog later. $\left({ }^{76}\right)$

\section{De halve fond}

$\mathrm{Bij}$ de halve fond, ook wel midfond genoemd, worden afstanden afgelegd die variëren tussen de 250 en de $500 \mathrm{~km}$. Voorbeelden van dergelijke vluchten zijn (afstanden opnieuw tot Gent gerekend): Breteuil (316 km), Orléans (372 km), Tours (461 km). ( $\left.{ }^{77}\right)$

Doorgaans begint het midfondseizoen iets later (ergens in april) en moeten de duiven iets langer recupereren waardoor ze slechts om de drie weken kunnen deelnemen aan wedstrijden. $\left({ }^{78}\right)$ In principe moet men dus meer duiven op z'n hok zitten hebben om halve fond te spelen, dan om deel te nemen aan de snelheidsvluchten. 
Een ideale duif voor de halve fond koppelt snelheid aan uithoudingsvermogen.

Hoewel de tijdsverschillen in deze categorie verder uit elkaar liggen, hebben we hier te doen met eendagswedstrijden die de zenuwen van de liefhebber niet té lang op de proef stellen.

De fond

Zoals reeds vermeld wordt de fond doorgaans opgedeeld in de lichte en de zware fond.

De maximale afstand die de duiven tijdens een lichte fondvlucht afleggen bedraagt ca. $800 \mathrm{~km}$. Dit is zowat de maximale afstand die een duif in één dag kan afleggen. Tijdens de zware fond wordt er steeds overnacht. Voorbeelden van lichte fondvluchten zijn: Bordeaux (759 km), Limoges $(606 \mathrm{~km})$, Poitiers (553 km) (afstanden tot Gent). Voorbeelden van zware fondwedstrijden zijn: Barcelona (1075 km), Dax (889 km), Lourdes (926 km), Marseille $(869 \mathrm{~km})$ (afstanden tot Gent).

Omwille van de grote afstanden die tijdens een dergelijke vlucht worden afgelegd, worden fondwedstrijden georganiseerd tijdens de langste dagen van het jaar (in juni en juli).

Fondduiven hebben een constitutie die vergelijkbaar is met deze van een marathonloper: ze zijn weinig explosief, maar hebben een groot uithoudingsvermogen. Het is voor de duivenmelker niet eenvoudig om goede fondduiven te kweken en af te richten. Wellicht verklaart dit voor een deel het relatief kleine aantal beoefenaars van de fonddiscipline (17\%).

Op de fond wordt ook nooit met jonge duiven gespeeld. Jongen die voorbestemd zijn voor de lange afstand worden best zoveel mogelijk gespaard en krijgen een aangepast trainingsschema waarbij de afstand stapsgewijs wordt opgetrokken. $\left({ }^{79}\right)$

$\mathrm{Na}$ een fondvlucht hebben de duiven nood aan een recuperatieperiode van vier weken.

\section{Indeling volgens de leeftijd van de duiven}

Schematisch samengevat bestaan er drie types van wedstrijden: de wedstrijden met jonge duiven, de wedstrijden met jaarlingen en de wedstrijden met oude duiven. $\left({ }^{80}\right)$

Jonge duiven kunnen al vanaf een ouderdom van drie en een halve

(79) QUICK R. Duivensporrforfunl. Gent, Het Volk, 1976, pp, 91-95.

(я0) BOUQUET Y.H., Op. Cit., p. 22. 
maand deelnemen aan wedstrijden, op voorwaarde dat de af te leggen afstand beneden de $300 \mathrm{~km}$ blijft.

Meestal richt men afzonderlijke wedstrijden in voor jongen en jaarlingen, het houdt immers geen steek om de prestaties van jongen te vergelijken met deze van oude duiven en vice versa.

Fondvluchten worden uitsluitend met oude duiven gespeeld omdat de ervaring, het uithoudingsvermogen en het oriëntatievermogen van de dieren op deze afstanden doorslaggevend zijn.

\section{De losplaatsen}

De meeste losplaatsen voor de Belgische duivenliefhebbers liggen tegenwoordig in Frankrijk, en ze liggen allen rond een imaginaire zuidwest/noordoost-as, waarbij de duiven in noordoostelijke richting vliegen. Dit is niet altijd zo geweest. Tijdens de tweede helft van de 19de eeuw en in het begin van de 20ste eeuw werden er geregeld vluchten vanuit Rome en Ajaccio georganiseerd. $\left({ }^{81}\right)$ Ook meer recent wordt er een vernieuwde interesse voor vluchten vanuit Duitsland, Engeland en Nederland waargenomen. ${ }^{82}$ )

Dit is opmerkelijk want duiven hebben geen nood aan een specifieke geografische ligging van de losplaats. Een en ander is dus historisch gegroeid en had wellicht meer te maken met de ontwikkeling van het Franse spoorwegennet, dan met het doelmatig nastreven van een bepaalde oriëntatie.

\section{Spelmethodes}

Duiven hebben aangeboren eigenschappen die hen in staat stellen hun hok terug te vinden. Alleen doen ze dat uit eigen beweging nogal op het gemak terwijl bij duivenwedstrijden het net de bedoeling is dat de duiven zo snel mogelijk vliegen.

De wedstrijdresultaten kunnen evenwel verbeterd worden door

(81) VAN DEN HOEK A., VAN GREMBERGEN G., HERMANS I., Het grote postduivenboek. Helmond - Antwerpen, Uitgeverij Helmond - Standaard Uitgeverij, s. d., pp. 11-12.

(82) HERMANS J., Op. Cit., p. 214.

(83) QUICK R. Duivensport totaal. Gent, litet Volk, 1976, p. 99. a) de dieren goed te oefenen of 'op te leren' en b) door de spelmethode. De kunst bestaat er in om de in te korven duif driftig te maken, waardoor de drang om naar huis terug te keren groter wordt. We onderscheiden een drietal speltechnieken.

\section{Het natuurlijk spel of het nestspel}

Bij deze methode wordt er gebruik gemaakt van de natuurlijke mogelijkheden of van de ideale nestpositie. $\left({ }^{{ }^{3}}\right)$ Bij deze spelvorm 
maakt de duivenmelker dus handig gebruik van de ouderinstincten van een duivenkoppel. De moeilijkheid hierbij is dat de twee geslachten verschillend reageren op de verschillende nestsituaties. Er bestaan wel algemene regels maar de duivenmelker moet over behoorlijk wat praktijkervaring beschikken om juist te handelen op het goede tijdstip.

Jan Hermans adviseert het volgende:

...nestduivinnen spelen op het broeden, op aangepikte eitjes en op jongen tot 12 dagen; nestdoffers leveren de beste prestaties op broeden, op jongen van 10 dagen en ouder, op jong in het nest en broeden en op drijven (jagen). Op platte jongen (één tot vijf dagen) noteren duivinnen zelden tot de verbeelding sprekende uitslagen, maar op de overnachtfond zien we juist overwinningen van de dames ... $\left.{ }^{84}\right)$

Omdat het nestspel op zich zelden ophefmakende resultaten oplevert, wordt het nog zelden in zijn zuiverste vorm gespeeld. Vaak wordt het nestspel gecombineerd met het weduwschap (zie verder), of worden er allerhande kunstgrepen toegepast om het prestatieniveau te verhogen. Zo worden de tussenschotten tussen de broedbakken vaak net voor het inkorven verwijderd om de jaloezie tussen de dieren onderling wat aan te scherpen of wordt de duivin tijdelijk van het nest gehaald, waarbij alle zorg aan het mannetje wordt overgelaten. $\left({ }^{85}\right)$

Het is echter een onbegonnen werk om alle varianten van het nestspel toe te lichten: zowat iedere melker die de nestmethode toepast heeft zijn eigen variant ontwikkeld en allen vinden ze hun methode veruit de beste...

Het grootste nadeel van het nestspel is dat men z'n duiven niet op om het even welk tijdstip kan laten deelnemen aan wedstrijden en dat men dus, wil men regelmatig spelen, een behoorlijk aantal duiven onder de pannen moet hebben.

\section{Het spel met de kotjes}

Dit is een spelvorm die gebruikmaakt van de vechtlust en jaloezie bij doffers. De methode levert vooral resultaten op bij korte afstanden. ${ }^{86}$ ) Het principe is vrij eenvoudig. Ieder koppel duiven beschikt over een afgesloten hokje met een afzonderlijke uitgang naar buiten die door middel van een schuif naar believen kan worden afgesloten. Al gauw geraken de bewoners van zo'n hok gehecht
(84) HERMANS I., Op. Gir.. p. 200.

(85) COLMAN F., Vadermecum 1939 noor de duivenliefnebbers. La Louvière, 1. C. I.. 1939. p. 20.

(86) QUICK R., Op. Cir., P. 96. 
aan hun stek. Is de tijd van de wedstrijd aangebroken, dan wordt de doffer buitengesloten (hij mag uitvliegen), waarna het schuifje wordt gesloten. Op hetzelfde moment wordt een andere, vreemde doffer (de beul) in het hok gezet. Lijdzaam moet de buitengesloten doffer toezien hoe de beul zijn duivin bespringt. Daarna wordt de buitengesloten doffer binnengelaten, deze wil de beul onmiddellijk toetakelen maar krijgt daar de kans niet toe: de twee worden gescheiden en de doffer wordt ingekorfd.

Het tonen van de beul is voldoende om de doffers razendsnel te doen binnenkomen. $\left({ }^{87}\right)$

Het nadeel van deze spelvorm is dat alle koppels afzonderlijk moeten gevoederd, uitgelaten en verzorgd worden.

\section{Het weduwschap}

Deze methode werd omstreeks 1900 door Belgische duivenmelkers op punt gesteld maar het zou tot 1930 duren alvorens de methode algemene ingang vond. $\left({ }^{88}\right)$ Tegenwoordig is het de meest toegepaste spelvorm.

Jonge doffers worden bij deze spelvorm gekoppeld aan oude duivinnen. Men laat ze samen één of twee jongen opbrengen $\left({ }^{89}\right)$ en bij het volgende nest scheidt men duivin en doffer als de jongen ongeveer 14 dagen oud zijn. Van dat moment af krijgen de doffers hun duivin nog slechts te zien net voor het inkorven. In het dofferhok werden daarvoor speciale (broed)hokken voor duivinnen ingericht die voorzien zijn van tralies. Als de doffers binnenkomen mogen ze een poos, de periode hangt af van de geleverde inspanning, $\left({ }^{90}\right)$ bij hun duivin verblijven, waarna ze opnieuw gescheiden worden. Ook het spel op het weduwschap vergt behoorlijk wat feeling van de kant van de duivenmelker: hij moet zijn doffers, vooral tegen het einde van het seizoen, gemotiveerd weten te houden, ze voldoende laten uitvliegen om de vorm te bewaren maar er toch op toezien dat de weduwnaars voldoende rusten.

Deze methode kan opmerkelijke resultaten opleveren en ook het binnenkomen vormt meestal geen enkel probleem.

(87) Idem.

(88) BOUQUET Y.H., Op. Cit., p 21.

(89) QUICK R, Op. Cit., p. 104.

(90) HERMANS J., Op. Cit., p. 198.
Een verdere evolutie van deze spelmethode is het totale weduwschap. Daarbij worden niet alleen de doffers maar ook de duivinnen ingekorfd. Het probleem dat zich daarbij kan voordoen is dat 
de duivin en de doffer elkaar onderweg tegenkomen en meer aandacht voor elkaar hebben dan voor het hok. $\left({ }^{91}\right)$

Naast het klassieke weduwschap en het totale weduwschap bestaat er nog een veelheid aan varianten, die elk hun specifieke voor- en nadelen hebben. Het valt immers buiten het opzet van dit artikel om op al deze afgeleide methodes in te gaan.

\section{Het africhten}

Duiven beschikken, zoals reeds tot vervelens toe vermeld, over een aangeboren vermogen om hun hok terug te vinden. Een doorgédreven trainingsprogramma kan deze natuurlijke gave echter sterk verbeteren.

Veel duivenmelkers houden er wat het africhten van duiven betreft een eigen filosofie op na, maar de krachtlijnen van een trainingsschema zijn toch steeds dezelfde.

Nog voor de jongen kunnen vliegen worden ze reeds in de spoetnik geplaatst zodat ze de onmiddellijke omgeving van het hok goed in zich kunnen opnemen.

Van zodra hun vliegvermogen enigszins ontwikkeld is zal de duivenmelker de jongen in groep laten uitvliegen om ze aldus vertrouwd te maken met de iets ruimere omgeving. Van zodra de dieren gaan stilzitten op de omliggende daken lokt men ze binnen en geeft ze wat te eten. Ook worden de duiven, met het oog op de latere verzending, van jongsaf aan gewend gemaakt aan de korven door ze nu en dan in een korf te voederen. $\left({ }^{92}\right)$

Daarna volgen een aantal 'opleervluchten' waarbij de duiven op korte afstand van het hok worden gelost (vaak bedraagt deze niet meer dan $1 \mathrm{~km}$ ). Om het terugvinden van het hok te vergemakkelijken worden bij de jongen vaak enkele hongerige oude duiven gevoegd die de jonge dieren de weg naar het hok helpen wijzen.

Vervolgens worden de afstanden stelselmatig opgetrokken tot 60 à $90 \mathrm{~km}$. Het organiseren van dergelijke vluchten gebeurt vaak in verenigingsverband om de duiven te doen wennen aan het vliegen in kladden.

Meestal zijn de losplaatsen zodanig gekozen dat ze in de lijn liggen van de toekomstige vliegroute van de wedstrijden.

Wanneer men duiven opleert voor fondwedstrijden zal men de afstanden van de oefenvluchten verder optrekken hoewel sommige

(91) lidem.

(92) BOUQUET Y.H., Op, Cit,, 20. 
(93) BAETEN E., Op. Cit., p. 151.

(94) Wil men jonge duiven of "soepen" uittesten in een wedstrijd dan kan voor deze duiven enkel de reiskosten betalen maar dan worden deze duiven niet opgenomen in het algemeen klassement.

(95) DANHIEUX L., "Inzetten bij het duivenspel" in: Biekorf, LXXIII, 1962, p. 115.

(96) Dit blijkt uit verschillende aankondigingen van wedstrijden in het duivenblad "De Vlaamsche duif".

(97) DANHIEUX L., op. Cit., p. 115.

(98) Ook tijdens het interbellum liepen de vrije inleggen soms op tot 100 frank, hoewel dit eerder uitzondering dan regel was: meestal variecrden de vrije inleggen tussen de 1 en de 20 frank (niet gedefleerd). melkers twijfelen aan het nut van dergelijke praktijken omdat lange oefenvluchten een negatieve invloed zouden hebben op de conditie van de dieren. $\left({ }^{93}\right)$

\section{Het inzetten}

Duivenwedstrijden zijn onlosmakelijk verbonden met het geldspel. Voor de professionele melker is het zijn bron van inkomsten, voor de liefhebber is het, zoals Jacques Nouwen dat zo treffend verwoordt, het element dat de sport kruidt.

Toch vallen duivenwedstrijden niet onder de wetgeving op de kansspelen, omdat het bij wet verboden is om geld in te zetten op de duiven van een ander, dit in tegenstelling tot bv. paardenraces.

\section{De verplichte inleg}

Wil men aan een prijskamp deelnemen dan is men verplicht om hoe kan het ook anders - de verplichte inleg te betalen. $\left({ }^{94}\right)$ Eventueel zijn de reiskosten (voedsel, huren treinstellen of vrachtwagens, vergoeden van de begeleiders...) in deze inleg inbegrepen, maar dit is niet noodzakelijk het geval. $\left({ }^{95}\right)$ Normaal geeft de verplichte inleg recht op één prijs per drie duiven. Een eenvoudig rekenvoorbeeld kan veel verduidelijken. In 1934 bedroeg de verplichte inleg voor een wedstrijd op Arras of Breteuil doorgaans 2 frank. $\left({ }^{96}\right)$

Stel dat er voor een dergelijke wedstrijd 300 duiven worden ingekorfd, dan bedraagt de totale verplichte inleg 600 frank $(300 * 2)$. Deze situatie levert 100 winnaars op die elk 6 frank $(2 * 3)$ krijgen. Van deze 100 duiven zegt men dat ze 'prijs vliegen', de overige duiven, 200 in het beste geval, zijn 'overduiven'. De andere te verdienen gelden kunnen zowel door prijsduiven als door overduiven gewonnen worden. $\left({ }^{97}\right)$

\section{De vrije inleg}

Naast de verplichte inleg kan de liefhebber ook intekenen, of 'steken', op de vrije inleg. Deze inleg, ook wel 'misen' genoemd geeft recht op een prijs per vier of per vijf duiven. Er bestaan misen van $1,2,3,4,5,10,15,20,25,50,75$ en $100\left(^{98}\right)$ (en soms nog meer). Als men een bepaalde mise steekt dan is men verplicht om ook alle voorgaande misen te steken. Als iemand dus voor 4 frank wil meedoen, dan is hij verplicht om in te tekenen op de misen van $1,2,3$ 
en 4 frank. Gesteld dat één duif op vijf prijsvliegt, dan kan men met een duif, waarop vrij ingelegd is tot vijf frank, $75\left(5^{\star} 1+5 * 2+5\right.$ $* 3+5 * 4+5 * 5$ ) frank winnen.

\section{Het poelen}

Voor hen die nog verder willen spelen bestaan er ook nog de poelen. Poelen verschillen eigenlijk niet van misen, alleen hebben deze reeksen een andere naam en zijn de bedragen die moeten ingezet worden doorgaans hoger. $\left({ }^{99}\right)$ Tijdens het interbellum was het gangbaar dat één gepoelde duif op acht in de prijzen vloog.

Het probleem dat zich bij het niet verplicht inleggen (de misen en de poelen dus) kan voordoen is dat het totaal aantal gepoelde duiven niet exact deelbaar is door 5 (voor de misen) of door 8 (voor de poelen). In zo'n geval zijn er twee mogelijke oplossingen: ofwel waarborgt de inrichtende maatschappij het poelegeld tot een bepaalde som (tijdens het interbellum bv. tot 1000 frank voor een vlucht op Breteuil) en dan zal ze het tekort zelf bijpassen tot deze som, ofwel betaalt men een aantal volledige poelen uit en een bijkomend 'overschot', dat dan per gepoelde reeks het resterende bedrag opstrijkt.

Een voorbeeld ter verduidelijking: als er 25 duiven gepoeld zijn tot 4 frank, dan hebben we drie winnaars die elk $80(1 * 8+2 * 8+3$

$* 8+4 * 8)$ frank verdienen en is er één winnaar die $10(1 * 1+2$

${ }^{*} 1+3 * 1+4 * 1$ ) frank mag meenemen naar huis.

Naast de gewone poelen zijn er op de belangrijke vluchten ook nog de speciale poelen. Het enige verschil met de gewone poelen is dat er per tiental wordt gespeeld. Tijdens het interbellum kwamen er voor Arras speciale poelen voor van 1, 2, 3, 4 en 5 frank. $\left({ }^{100}\right)$

\section{De speciale prijzen}

Naast de misen en de poelen zijn er de speciale prijzen. De belangrijkste zijn: 'de heeft', 'de scher(r)eweg', 'de unique' en 'het kampionaat'.

De heeft wordt meestal meer voor het plezier dan voor het geld gespeeld. De inzet is doorgaans niet groot $\left({ }^{101}\right)$ en de totale som wordt in vijf gelijke delen verdeeld onder de eerste vijf duiven die voor de heeft hebben ingelegd. $\left({ }^{102}\right)$
(99) DANHIEUX L., Op. Cit., p. 116.

(100) Dit blijkt uit de inzage van verschillende jaargangen van "De Vlaamsche duif".

(101) Op Arras en Breteuil bedroeg de inleg voor de heeft tijdens het interbellum ca. 5 frunk.

(102) DANHIEUX L. OP. Cir., p. 110. 
Bij schereweg of - in West-Vlaanderen - scherreweg gaat al het prijzengeld naar de eerste duif die ervoor in aanmerking komt. De inleg voor de scherreweg is altijd lager dan bij de heeft. $\left({ }^{103}\right)$ Bij de unique wordt het totale bedrag in een aantal gelijke schijven verdeeld over een aantal duiven. De grootte van deze schijven is afhankelijk van de wedstrijd en van de inrichters.

Het kampionaat is vergelijkbaar met de unique, maar de te winnen bedragen zijn doorgaans groter. $\left({ }^{104}\right)$

Tot slot is er nog de 'grote prijs'. Deze wordt meestal tot een hoog bedrag gewaarborgd door de inrichtende maatschappij en heeft een lage inleg (tijdens het interbellum: 1 frank). De totale prijzenpot wordt verdeeld onder de eerste twee duiven die ervoor intekenden. De eerste van deze twee duiven krijgt $2 / 3$ van het totale bedrag, de tweede duif het resterende derde deel.

\section{De series}

Dit onderdeel is/was vooral populair bij duivenmelkers die zich in de snelheidsvluchten specialiseerden. Bij dit spelonderdeel gaat het niet meer om de prestaties van een individuele duif maar om de collectieve prestatie van een reeks duiven. Hierbij zijn er twee mogelijkheden. Ofwel kan de duivenmelker, bij het inkorven, de volgorde van binnenkomen van een reeks duiven aanduiden, dan spreekt men van een 'aangeduide serie', ofwel doet hij dat niet en dan spreekt men van een 'onaangeduide serie'. ${ }^{105}$ )

Een serie bestaat doorgaans uit twee, drie of vier duiven. Vaak zijn er met series prijzen in natura te winnen (een varken, een schouwgarnituur, een koffieservies...) maar het is evengoed mogelijk dat de totale prijzenpot (gelijk) wordt verdeeld over de eerste tien of twintig geconstateerde series.

Tot slot zijn er nog de 'ere-series' die in feite niets anders zijn dan aangeduide series van twee duiven, alleen is de inleg en het te winnen prijzengeld bij ere-series groter. ${ }^{(106)}$

(103) tijdens het interbellum ca. 2 frank. (104) DANIIIEUX L., Op. Cit., p. 116. (105) DANHIEUX L., Op. Cit.,p. 117. (I(K) Idem.

\section{De wedstrijd}

In dit hoofdstuk zullen we wat nader ingaan op het eigenlijke verloop van de wedstrijd. Er komt immers meer bij kijken dan men op 
het eerste zicht zou vermoeden: om een duivenwedstrijd te organiseren moet men over een goed werkend logistiek en communicatief net beschikken.

\section{Het inkorven en ringen}

Vooraleer de duiven kunnen worden verzonden naar de losplaatsen moet men de duiven eerst verzamelen en voorzien van een wedstrijdring. De dag van de inkorving is eveneens de dag waarop de weddenschappen kunnen worden afgesloten.

Tegenwoordig gebeuren deze handelingen, afhankelijk van de lengte van de vlucht, op de dag van de wedstrijd (vitesse, halve fond) of enkele dagen op voorhand (fond) maar het spreekt vanzelf dat, in de tijd dat de duiven te voet naar de losplaats werden gebracht, de inkorving voor alle afstanden dagen op voorhand moest gebeuren. De deelnemers aan de wedstrijd moeten zich op een vooraf vastgelegd moment met hun dieren begeven naar het inrichtende duivenlokaal, waar de duiven met behulp van een speciaal apparaat, een soort tang die op een tafel gemonteerd staat, van een gummiring of wedstrijdring worden voorzien.

Van zodra de duiven voorzien zijn van een wedstrijdring en de poelebrieven zijn ingevuld, worden de dieren in verzendingsmanden ingekorfd. Zoals reeds hoger vermeld is het type van verzendingsmand afhankelijk van het transportmiddel waarmee de duiven worden vervoerd.

\section{De begeleiding}

Op de tocht naar de losplaatsen worden de duiven vergezeld door begeleiders of convoyeurs $\left({ }^{107}\right)$ zoals het in het jargon klinkt.

De convoyeurs zijn in de eerste plaats diegenen die de manden openen op de losplaatsen, maar hun verantwoordelijkheid reikt verder. Gebeurt de verzending per trein of per vliegtuig, dan zijn zij begeleiders in de letterlijke zin van het woord en moeten ze er op toezien dat de duiven voldoende te eten of te drinken hebben, dat de verluchting optimaal is, dat de verlichting of verduistering in orde is - kortom dat de dieren in optimale omstandigheden aan de start verschijnen. Gebeurt de verzending per vrachtwagen, dan zijn zij eveneens chauffeur.

(107) Ook in Nederlandse werken en weekbladen wordt deze term gebruiks. 
In de begindagen van de duivensport werden de dieren in hoofdzaak begeleid door vrijwilligers van de inrichtende vereniging.

Aan het einde van de 19de eeuw kende het spoorwegennet een aanzienlijke uitbreiding. Vanaf $1879\left({ }^{108}\right)$ werd er dan ook gebruik gemaakt van dit nieuwe vervoermiddel om de duiven naar hun bestemming te brengen. Aanvankelijk waren de enige begeleiders de stationsoversten die, geheel volgens hun eigen inzichten, instonden voor het transport en de lossing. Zij namen het daarbij niet altijd zo nauw met de verzorging tijdens de treinrit en ook het lossingstijdstip werd vaak onnauwkeurig doorgegeven.

Tegen het einde van de vorige eeuw...werden er geene ernstige prijskampen meer ingericht, of de loslating der Duiven is door eenen geleider gedaan: 't is overigens alleenlijk op die wijze dat de vogels wel bezorgd kunnen wezen en dat de prijskamp met waarborg, nauwkeurig-en rechtveerdigheid kan uitgevoerd worden ... $\left({ }^{109}\right)$

De taak van deze begeleiders, die vaak vrijwilligers waren, werd in het begin van deze eeuw steeds vaker overgenomen door derden. $\left({ }^{110}\right)$ Aanvankelijk waren zij nauwelijks uitgerust om hun taak naar behoren uit te voeren: vaak maakten ze gebruik van huurwagens die op gezette tijdstippen terug bij de verhuurder moesten staan (waardoor er, door tijdsgebrek, niet altijd op het ideale moment werd gelost). ('"') Gelukkig (voor de liefhebbers) behoren deze problemen tot het verleden.

Het spreekt vanzelf dat deze gespecialiseerde verzendingsbedrijven hun diensten niet gratis aanboden, wel integendeel: de verzendingskosten konden aanzienlijk doorwegen op het budget van de duivenmelker. Zo werd er, bij wijze van voorbeeld, in 1937, door de firma Ampe en Depoorter, $\left({ }^{112}\right)$ voor Arras 15 frank aangerekend en voor Breteuil 24 frank, wat omgerekend naar hedendaagse bedra-

(108) WITTOUCK S., Op. Cit., p. 262. (109) WITTOUCK S., Op. Cit., p. 263.

(110) Fen mooi voorbeeld hierbij is de verzendingsmaatschappij “De Vlaanders” van duivel-doet-al Abdon Depoorter.

(111) HERMANS J., Op. Cit., p. 209.(112) Prive-archief Luc Devlieghere, wonder nummer.

(112) ?? gen overeenstemt met respectievelijk 337 fr. (8,35 euro) en 539 fr. (13,36 euro).

\section{De communicatie}

We kunnen het ons nog moeilijk voorstellen, maar de factor communicatie heeft jarenlang een bepalende stempel op de duivensport gedrukt. Tot de tweede helft van de 19de eeuw waren de meeste communicatiemiddelen trager dan de naar hun hok vliegende duiven, wat tot gevolg had dat de duivenmelkers vaak niet 
eens wisten wanneer hun duiven gelost werden. Hoewel de bronnen hierover vaag blijven, kan men vermoeden dat een dergelijke situatie zo nu en dan tot algehele verwarring moet hebben geleid. De opkomst van de telegraaf, en iets later de telefoon - in onze contreien was dit in de laatste decennia van de 19de eeuw - betekende een serieuze stap in de goede richting. Voortaan kon het exacte lossingstijdstip via een telegram of een telefoonbericht aan de organiserende maatschappijen worden meegedeeld. $\left({ }^{113}\right)$ Deze praktijk bleef in voege tot ca. 1925 - 1930. Om de prijs van de telegrammen te drukken en de snelheid ervan te verhogen werd (althans door de firma Depoorter \& Ampe) gebruik gemaakt van een codesysteem, waarbij elke weersgesteldheid overeen kwam met de naam van een voertuig. ${ }^{114}$ )

In 1932 begon het N. I. R. met regelmatige uitzendingen en al gauw werd daar door de organiserende maatschappijen gretig gebruik van gemaakt. De eerste aanvragen tot het uitzenden van 'informatie voor duivenliefhebbers' dateren uit het begin van de jaren '30. (115)

\section{Het weer}

Om de duiven een optimale kans op thuiskomen te geven wordt er nauwgezet op toegezien dat de omstandigheden bij het lossen gunstig zijn. Maar goede weersomstandigheden bij het lossen zijn natuurlijk geen garantie voor goede weersomstandigheden onderweg.

De grootste boosdoeners zijn mist- en nevelslierten en inversies. Deze laatste zijn verschijnselen waarbij warme en vochtige luchtlagen afgewisseld worden door droge en koude luchtlagen. Kort samengevat komt het er op neer dat deze luchtlagen een verschillende brekingsindex (van licht) hebben, waardoor ze gaan werken als een panparallelle plaat. Daardoor komt de zon, en bijgevolg ook het hok, te staan op een plaats waar ze niet zijn. ( $\left.{ }^{116}\right)$ Tegenwoordig maakt men volop gebruik van de diensten van de meteowing van het leger, maar in vroegere tijden deden de begeleiders vooral een beroep op hun ervaring.

\section{Het lossen}

Als de duiven eenmaal ter plaatse zijn aangekomen en de weersomstandigheden zijn gunstig, dan kunnen de duiven in principe

(113) WITTOUCK S., Op, Cit., p. 262. (1 14) Prive-archicf Lue Devlieghere.

(115) $\mathrm{ldem}$.

(II6) VANDEN HOEK, OR, Cir.. R. 28. 
worden gelost. In vele gevallen gebeurt deze handeling nog steeds manueel. Dit wil zeggen dat alle manden, die in rijen opeengestapeld staan, één voor één geopend worden door de begeleiders. Daarbij gaat men steeds van onder naar boven te werk.

Opdat de winstkansen van iedereen even groot zouden zijn is het van groot belang dat de begeleiders snel en efficiënt werken zodat het tijdsverschil tussen de eerst geloste duiven en het openen van de laatste manden zo klein mogelijk is.

Het spreekt vanzelf dat de invloed van eventuele tijdsverschillen bij fondvluchten kleiner wordt, en dat is maar goed ook want het aantal deelnemende duiven bij dergelijke vluchten is vaak immens.

\section{Het constateren}

Hier beperken we ons tot het kort herhalen van de constatatietechniek die gedurende het grootste deel van de 20ste eeuw - dus ook in het interbellum - in voege was.

Zoals reeds eerder werd vermeld werden de binnenkomende ('vallende') duiven van hun wedstrijdring ontdaan. Die werd in een koperen 'potje' gestopt en op zijn beurt in de constateur gebracht wat de tijdsvaststelling teweegbracht.

$\mathrm{Na}$ de wedstrijd begaf de duivenmelker zich met zijn constateur(s) naar het duivenlokaal. Daar werd vastgesteld hoeveel de constateur voor- of achterliep ten opzichte van de moederklok. Daarna werden de klokken geopend om de constatatietijdstippen vast te stellen.

\section{Het klassement}

Alle constatatietijden worden nu samengebracht en verwerkt tot één grote uitslagenlijst waarop eveneens het gewonnen (of verloren) prijzengeld valt af te lezen: de spiegellijst. De eigenlijke klassering gebeurt op basis van de gemiddelde vliegsnelheid (in meter per

(117) Vaak worden enkel de naam van de binnen de tijd geklasseerde duivenmelkers en het totaal gewonnen bedrag per duif vermeld zonder dat daarbij gespecificeerd wordt hoe er werd ingezet (misen, poelen ...). Heel soms worden ook de ringnummers van de duiven mee afgedrukt. minuut) van de deelnemende duiven.

De spiegellijsten worden geafficheerd in het inrichtende duivenlokaal en vaak worden er (samenvattende) afschriften ( ${ }^{117}$ ) van gepubliceerd in de gespecialiseerde pers.

\section{Wettelijke bepalingen}

Doorheen de geschiedenis van de duivensport heeft de overheid altijd een meer dan gewone interesse getoond voor het spel en dit 
in hoofdzaak om twee redenen: ten eerste omdat er behoorlijk wat geld mee gemoeid was / is, wat kan leiden tot ontsporing en gokverslaving maar ook belastingsperspectieven opent en ten tweede omdat duiven zouden kunnen worden ingezet voor spionagedoeleinden.

Via een aantal wetten en Koninklijke Besluiten onderwierp de overheid de duivenliefhebberij aan een vrij stugge regelgeving al moet het gezegd dat de eigenlijke wetgeving vrij laat tot stand kwam. De eerste aanvragen tot wijziging van het Landelijk Wetboek dateert reeds van 7 oktober $1886\left({ }^{118}\right)$ terwijl de eerste wetten pas 40 jaar later zouden worden uitgevaardigd.

\section{Nabeschouwing}

Met dit artikel werd een poging ondernomen om zowel de relatie mens - duif als de duivensport historisch te kaderen. Daarbij werd een korte biologische zijsprong gemaakt.

Daaruit blijkt dat de weg die werd afgelegd om te komen tot het spel met de duiven zoals het vandaag nog gespeeld wordt behoorlijk lang was.

De teneur van het betoog bleef uit pragmatische overwegingen vrij algemeen maar onderzoek in het kader van een licentiaatsverhandeling $\left({ }^{119}\right)$ leerde ons dat het gegeven duivensport ook op een compleet andere manier benaderd kan worden: her en der blijken er immers voor de historicus zeer interessante bronnenreeksen (vooral uitslagen van wedvluchten) bewaard gebleven die kunnen bijdragen tot een beter inzicht in het bestedingspatroon van hen die de duivensport beoefenden in een nauwkeurig afgebakend gebied en voor een bepaalde periode. Op deze manier kan een sport met een licht imagoprobleem een bijdrage leveren tot de geschiedschrijving van de voorbije honderd jaar ... 